\title{
The interaction between Histoplasma capsulatum cell wall carbohydrates and host components: relevance in the immunomodulatory role of histoplasmosis
}

\author{
Patricia Gorocica ${ }^{1}{ }^{+}$, Maria Lucia Taylor ${ }^{2}$, Noé Alvarado-Vásquez ${ }^{1}$, Armando Pérez-Torres ${ }^{3}$, \\ Ricardo Lascurain ${ }^{1} / 4$, Edgar Zenteno ${ }^{4}$ \\ 'Departamento de Bioquímica, Instituto Nacional de Enfermedades Respiratorias, 14080 México, DF, México ²Microbiología y Parasitolo- \\ gia ${ }^{3}$ Biología Celular y Tisular ${ }^{4}$ Bioquímica, Facultad de Medicina, Universidad Nacional Autónoma de México, México, DF, México \\ Histoplasma capsulatum is an intracellular fungal pathogen that causes respiratory and systemic disease by \\ proliferating within phagocytic cells. The binding of $\mathrm{H}$. capsulatum to phagocytes may be mediated by the pathogen's \\ cell wall carbohydrates, glucans, which consist of glucose homo and hetero-polymers and whose glycosydic link- \\ age types differ between the yeast and mycelial phases. The $\alpha-1,3$-glucan is considered relevant for $\mathrm{H}$. capsulatum \\ virulence, whereas the $\beta-1,3$-glucan is antigenic and participates in the modulation of the host immune response. \\ H. capsulatum cell wall components with lectin-like activity seem to interact with the host cell surface, while host \\ membrane lectin-like receptors can recognize a particular fungal carbohydrate ligand. This review emphasizes the \\ relevance of the main $\mathrm{H}$. capsulatum and host carbohydrate-driven interactions that allow for binding and internal- \\ ization of the fungal cell into phagocytes and its subsequent avoidance of intracellular elimination.
}

Key words: Histoplasma capsulatum - carbohydrates - glucans - polysaccharides - immunomodulation

Histoplasma capsulatum is an ubiquitous dimorphic intracellular fungal pathogen which exists in either a mycelial (saprobe-infective form) or a yeast (parasiticvirulent form) phase. The characterization of outer carbohydrates specific to these phases may lead to a better understanding of their pathogenic fungal-host interactions, such as fungal adhesion, internalization and host immune evasion mechanisms. Therefore, this review focuses on specific fungal saccharidic structures that may be involved in the aforementioned mechanisms.

The chemical characteristics and the functions of H. capsulatum cell wall carbohydrates

The cell wall is essential to almost every aspect of $H$. capsulatum biology and pathogenicity. In general, $80 \%$ of the fungal cell wall's dry weight is composed of saccharides (Bernard \& Latgé 2001). Glucose (Glc), followed by mannose (Man) and galactose (Gal), is the most abundant monosaccharide found in $H$. capsulatum cell walls during the mycelial and yeast phases. It has been reported that polymers of Glc (glucans) and N-acetyl-glucosamine (GlcNAc) called chitin are the major components of the H. capsulatum cell wall (Kanetsuna et al. 1974). The concentration of saccharides can vary depending on culture medium composition, environmental conditions, strain type and the extraction method used (Domer et al. 1967, Kanetsuna et al. 1974, Reiss et al. 1977).

+Corresponding author: pgorocica@yahoo.com.mx

Received 15 July 2008

Accepted 26 January 2009
It has been proposed that glucans play an important role in fungal host-cell interactions. There are differences between the glucan glycosydic linkages in the cell walls of the $H$. capsulatum yeast and mycelial phases. The $\alpha$ and $\beta$-glucans present in the cell walls of these morphological phases have different biological roles (Domer et al. 1967, Domer 1971, Gómez et al. 1991). An $\alpha$-glucan contains $\alpha$-1,3-glucosyl linear residues, while $\beta$-glucan consists of a linear $\beta$-1,3-glucosyl-linked backbone with $\beta$-1,6-glucosyl-linked side chains that vary in length and distribution, while forming a complex tertiary structure stabilized by interchain hydrogen bonding (Kanetsuna et al. 1974). The yeast cell wall contains an inner layer of chitin, a polysaccharide composed of $\beta-1,4-$ GlcNAc residues, and an outer fibrous-layer of $\alpha-1,3$-glucan (Kanetsuna et al. 1974). Topographically, the $\alpha-1,3$-glucan overlaps the $\beta$-glucan polymer in the yeast cell wall. The yeast and mycelia phases of $H$. capsulatum contain different chitin fibril arrangements within their cell walls (Kanetsuna 1981).

Based on the $\alpha-1,3$-glucan concentration in the yeast cell wall, $H$. capsulatum is classified as chemotype I and II (Domer et al. 1967, Domer 1971). A chemotype II cell wall contains of a mixture of $\alpha$ and $\beta$-glucans, with glucan predominantly linked in the $\alpha$-configuration, while chemotype I is entirely $\beta$-linked (Davis et al. 1977). Moreover, the cell walls of $H$. capsulatum chemotype I strains contain more chitin and less glucan than chemotype II (Domer et al. 1967, Domer 1971).

In general, fungal chitin is considered to play both a structural role in maintaining cell wall rigidity, as well as in resisting the environment (Ruiz-Herrera 1992). It is also possible that chitin has a dual immunomodulatory effect on macrophages by immunosuppressing or 
activating anti-microbial mechanisms by increasing nitric oxide production, an activity previously described in Candida albicans (Rementeria et al. 1997).

The presence of $\alpha-1,3$-glucans in $H$. capsulatum has previously been associated with strain virulence (Kügler et al. 2000, Rappleye et al. 2007). Alternatively, $\beta$-glucan, which is predominant in the fungal mycelial phase, participates in both leukocyte recruitment and the upregulation of inflammatory mediators, such as leukotrienes (Medeiros et al. 1999).

A temperature-induced phase transition may modify the biosynthesis of glucans, i.e., the synthesis of $\alpha-1,3-$ glucan is a special attribute of $H$. capsulatum yeast phase (Kanetsuna et al. 1974, Klimpel \& Goldman 1988). In recent studies, $\alpha-1,4$-amylase has been involved in both the synthesis of $\alpha-1,3$-glucan and the virulence of $H$. capsulatum (Marion et al. 2006). Virulent $H$. capsulatum strains contain up to 1,000 -fold more $\alpha$-1,3-glucan than avirulent strains do. Some $H$. capsulatum strains spontaneously produce avirulent variants lacking $\alpha-1,3-$ glucan. These can persist for several weeks inside macrophages and adopt an unusual morphology, similar to those variants reported in tissues of chronically infected humans and other mammals (Klimpel \& Goldman 1988). The $\alpha-1,3$-glucans may contribute to the establishment of intracellular latency (Eissenberg et al. 1996, 1997), regulate yeast proliferation inside a host macrophage (Kügler et al. 2000) and protect yeast within phagolysosomes (Eissenberg \& Goldman 1991). Moreover, the low TNF- $\alpha$ produced by infected host cells provides indirect evidence for an $\alpha$-1,3-glucan-mediated effect on the hostparasite relationship (Rappleye et al. 2004, 2007). It has also been suggested that $\alpha$-1,3-glucan can block innate immune recognition of $H$. capsulatum by a particular $\beta$-glucan receptor (Rappleye et al. 2007).

Cell wall mannans (Man-containing polysaccharides) and mannosylated proteins are important fungal antigens and have been implicated in host tissue adherence (Ross 2002). Galactomannan-protein complexes from the mycelial phase cell wall of $H$. capsulatum have antigenic properties; they can induce delayed-type hypersensitivity in guinea pigs and inhibit macrophage migration factor release (Azuma et al. 1974, Reiss et al. 1974). A deproteinized polysaccharide-protein complex isolated from $H$. capsulatum, which immunolocalized mainly to the mycelial phase cell wall by colloidal gold labelling (Taylor \& Bojalil 1977, Taylor et al. 1980, Pereira-Morales et al. 1998), shares common characteristics with the galactomannan-protein complex reported by Reiss et al. (1974). Fungal galactomannan complexes may be involved in a mechanism to protect the organism against its own serinethiol protease, an enzyme associated with pathogen dissemination through the extracellular matrix, as described in paracoccidioidomycosis (Matsuo et al. 2006).

The fungal cell wall contains a low proportion of lipids, of which several are linked to carbohydrates and illustrate structural heterogeneity. In H. capsulatum, sphingolipid modifications may be functionally relevant for their growth, life cycle, morphogenesis, and host-pathogen interactions (Dickson \& Lester 1999). Adherence to the membrane of host cells by $H$. capsulatum seems to be mediated by lactosylceramide (Gal $\beta 1-4 \mathrm{Glc} \beta 1$ 1Cer) (Jiménez-Lucho et al. 1990). Lactosylceramide is the major glycosphingolipid in the host cell and seems to be an important component of some receptor moieties participating in yeast adherence to phagocytes and other host cells, an event that probably favours fungal dissemination (Obei et al. 2002). The glycosylinositol phosphorylceramides present in the mycelial and yeast phases of $H$. capsulatum (Barr et al. 1984, Barr \& Lester 1984) seem to be required for fungal survival (Dickson \& Lester 1999).

\section{The interactions between $\boldsymbol{H}$. capsulatum cell wall carbohydrates and host cells}

The molecular interactions between host cells and $H$. capsulatum are critical events in the intracellular fate of this fungus, as well as in the pathogenesis of histoplasmosis. Microorganisms initially trigger the immune system by activating the innate immune response, which is based on recognition of pathogen-associated molecular patterns (PAMPs). $\beta$-Glucans possess many of the characteristics attributed to PAMPs and are known to be potent triggers of innate immunity (Brown 2006).

Different host receptors can interact specifically with fungal carbohydrates, especially the lectin-like receptors, including the Man receptor (CD206); $\beta$-glucan receptors, such as Dectin-1 and DC-SIGN (CD209); complement receptor-3 (CR3 or CD11b/CD18); and collectins, such as surfactant factors (SP-A and SP-D) and pentraxin-3. These are considered pattern recognition receptors (PRRs) and are present in both professional and non-professional host phagocytes, including macrophages, dendritic cells (DC) and epithelial cells (Brown 2006, Dennehy \& Brown 2007).

Dectin-1, a nonclassical C-type lectin found in neutrophils, natural killer cells, DC and a subset of T cells is important for the detection of glycosylated fungal components (Brown 2006). It is a major nonopsonic $\beta$-glucan receptor and one of the first PRRs identified that can mediate its own signalling, as well as being able to act synergistically with Toll-like receptors (TLR) to initiate specific responses to infectious agents. It can also mediate signals to induce inflammatory responses to $\beta$-glucans from several fungal pathogens (Brown 2006, Dennehy \& Brown 2007). Several PAMPs located in the cell wall or on other fungal cell surfaces have been identified as potential ligands for TLR-2 and TLR-4 and have been implicated in host defence against some pathogenic fungi (Meier et al. 2003, Roeder et al. 2004). However, the participation of TLRs in histoplasmosis has not been confirmed.

It has been suggested that $H$. capsulatum $\alpha-1,3-$ glucans block host Dectin-1 from recognizing $\beta$-glucans present during the fungal yeast phase (Rappleye et al. 2007). This implies that the $\alpha-1,3$-glucans act as "decoy ligands" for the Dectin-1 receptor. However, several membrane components, such as CR3, the scavenger receptor, and Gal $\beta 1-4 \mathrm{Glc} \beta 1-1 \mathrm{Cer}$, have been shown to interact with $\beta$-glucan (Kataoka et al. 2002). Consequently, the abrogation of the host innate immune response by blocking Dectin-1 with $\alpha-1,3$-glucan may be circumvented by other $\beta$-glucan receptors or Gal $\beta 1-4$ Glc $\beta 1$ $1 \mathrm{Cer}$ molecules during natural host interactions. 
At present, the specific receptors recognizing $H$. capsulatum $\alpha-1,3$-glucan have not been identified. However, Bittencourt et al. (2006) recently described the participation of cell wall $\alpha-1,3$-glucan in the phagocytic internalization of Pseudallescheria boydii, which stimulated the secretion of inflammatory cytokines through the involvement of TLR2, CD14, and MyD88.

As previously described, $H$. capsulatum $\beta$-glucan favours the production of inflammatory mediators (Medeiros et al. 1999). In general, activation of macrophages by several types of soluble $\beta$-glucans culminates in the induction of proinflammatory mediators, nitric oxide synthase, TNF- $\alpha$ and macrophage inflammatory protein-2 (Kataoka et al. 2002, Deepe \& Gibbons 2006, Deepe 2007).

CR3 is considered the main macrophage lectin-like receptor involved in nonopsonic recognition of $H$. capsulatum yeast (Long et al. 2003). H. capsulatum yeast bind to CD18 $\beta 2$-chains of integrin, CR3 (CD11b/CD18), LFA-1 (CD11a/CD18) and to CR4/p150/95 (CD11c/CD18) on macrophages (Bullock \& Wright 1987). Heat shock protein 60 seems to be the major ligand mediating $H$. capsulatum yeast and conidia binding to the $\mathrm{CD} 18$ chain of CR3 on macrophages (Long et al. 2003). It has been reported that signalling via CR3 down-regulates IL-12 production in response to $H$. capsulatum. Consequently, the lower production of IL-12 abolishes its protective response against fungi (Marth \& Kelsall 1997). It is well known that the CR3 molecule contains a lectin domain with specificity for polysaccharides containing Man, GlcNAc and Glc (Xia et al. 1999, Ross 2002). In addition, lectin-mediated interactions between CR3 and several microbial ligands abrogate the release of toxic oxygen metabolites. Therefore, CR3 functions as a receptor for soluble and particulate polysaccharides and may act as a safe portal for the entry of an intracellular microorganism into macrophages.

Another lectin-mediated interaction between $H$. capsulatum yeast and host cells has been considered, in which lectin activity is associated with a component present on the yeast cell surface. This lectin-like activity is specific to galactosylated surface molecules (mainly $\beta$-anomer) on murine macrophages (Taylor et al. 1998, Duarte-Escalante et al. 2003). H. capsulatum yeast also has the ability to bind and agglutinate human erythrocytes through this lectin-like component (Taylor et al. 2004). The biological significance of these findings seems to be related to aspects of dissemination and pathogenesis of the associated clinical disease. The $H$. capsulatum lectin recognizes a $68-\mathrm{kDa}$ cell surface protein on murine macrophages (Taylor et al. 1998). This membrane receptor seens to participate in mechanisms that activate macrophages and those that regulate phagocytosis (Maldonado et al. 1998).

In some cases, opsonins are required to capture fungi by phagocytic lectin-like receptors. Serum opsonins that have lectin-like receptor activity, such as CR3 and the family of collectin molecules, play an important role in the immune response against microorganisms ( $\mathrm{Lu}$ et al. 2002). Collectins play a dual role in the innate response: as a possible mechanism for dissemination (McMahon et al. 1995) and as serum opsonin (McCormack et al. 2003). The collectins commonly associated with $H$. capsulatum are lung surfactant proteins A and D (SP-A and SP-D) and Man-binding lectin. SP-A and SP-D provide a mechanism to control $H$. capsulatum proliferation during the preinflammatory phase of the host-pathogen interaction. Both collectins inhibit fungal growth by increasing the microorganism's permeability and circumventing its aggressiveness. H. capsulatum is protected from collectinmediated killing by rapidly entering pulmonary macrophages (McCormack et al. 2003).

Surface carbohydrates on numerous pathogens are important for the early activation of the innate immune response and the subsequent control and destruction of these pathogens. H. capsulatum utilizes its cell wall carbohydrates or the host cell surface carbohydrates to bind and colonize the host, as well as to activate the innate response. Moreover, they seem to provide H. capsulatum with the capacity to survive in macrophages. The cell wall is the major fungal structure involved in interactions with the host. It is a highly dynamic entity and changes in its composition or structure may trigger critical consequences for the host-parasite relationship.

\section{ACKNOWLEDGEMENT}

To Ingrid Mascher, for editorial assistance.

\section{REFERENCES}

Azuma I, Kanetsuna F, Tanaka Y, Yamamura Y, Carbonell LM 1974. Chemical and immunological properties of galactomannans obtained from Histoplasma duboisii, Histoplasma capsulatum, Paracoccidioides brasiliensis and Blastomyces dermatitidis. Mycopath Mycol Appl 54: 111-125.

Barr K, Laine RA, Lester RL 1984. Carbohydrate structures of three novel phosphoinositol-containing sphingolipids from the yeast Histoplasma capsulatum. Biochemistry 23: 5589-5596.

Barr K, Lester RL 1984. Occurrence of novel antigenic phosphoinositol-containing sphingolipids in the pathogenic yeast Histoplasma capsulatum. Biochemistry 23: 5581-5588.

Bernard M, Latgé JP 2001. Aspergillus fumigatus cell wall: composition and biosynthesis. Med Mycol 39 (Supl. 1): 9-17.

Bittencourt VC, Figueiredo RT, da Silva RB, Mourão-Sá SD, Fernande P, Sassaki GL, Mulloy B, Bozza MT, Barreto-Bergter E 2006. An $\alpha$-glucan of Pseudallescheria boydii is involved in fungal phagocytosis and toll-like receptor activation. $J$ Biol Chem 218: 22614-22623.

Brown GD 2006. Dectin-1: a signalling non-TLR pattern-recognition receptor. Nat Rev Immunol 6: 33-43.

Bullock WE, Wright SD 1987. Role of the adherence-promoting receptors, CR3, LFA-1, and p150,95, in binding of Histoplasma capsulatum by human macrophages. $J$ Exp Med 165: 195-210.

Davis TE Jr, Domer JE, Li YT 1977. Cell wall studies of Histoplasma capsulatum and Blastomyces dermatitidis using autologous and heterologous enzymes. Infect Immun 15: 978-987.

Deepe GS Jr 2007. Tumor necrosis factor alpha and host resistance to the pathogenic fungus, Histoplasma capsulatum. J Invest Dermatol Symp Proc 12: 34-37.

Deepe GS Jr, Gibbons RS 2006. T cells require tumor necrosis factor a- to provide protective immunity in mice infected with Histoplasma capsulatum. J Infect Dis 193: 322-330. 
Dennehy KM, Brown GD. 2007. The role of the $\beta$-glucan receptor Dectin-1 in control of fungal infection. J Leukoc Biol 82: 253-258.

Dickson RC, Lester RL 1999. Yeast sphingolipids. Biochem Biophys Acta 1426: 347-357.

Domer JE 1971. Monosaccharide and chitin content of cell walls of Histoplasma capsulatum and Blastomyces dermatitidis. J Bacteriol 107: 870-877.

Domer JE, Hamilton JG, Harkin JC 1967. Comparative study of the cell walls of the yeast-like and mycelial phases of Histoplasma capsulatum. J Bacteriol 94: 466-474.

Duarte-Escalante E, Zenteno E, Taylor ML 2003. Interaction of Histoplasma capsulatum yeasts with galactosylated surface molecules of murine macrophages. Arch Med Res 34: 176-183.

Eissenberg LG, Goldman WE 1991. Histoplasma variation and adaptive strategies for parasitism: new perspectives on histoplasmosis. Clin Microbiol Rev 4: 411-421.

Eissenberg LG, Moser SA, Goldman WE 1997. Alterations to the cell wall of Histoplasma capsulatum yeasts during infection of macrophages or epithelial cells. J Infect Dis 175: 1538-1544.

Eissenberg LG, Poirier S, Goldman WE 1996. Phenotypic variation and persistence of Histoplasma capsulatum yeasts in host cells. Infect Immun 64: 5310-5314.

Gómez AM, Rhodes JC, Deepe GS Jr 1991. Antigenicity and immunogenicity of an extract from the cell wall and cell membrane of Histoplasma capsulatum yeast cells. Infect Immun 59: 330-336.

Jiménez-Lucho V, Ginsburg V, Krivan HC 1990. Cryptococcus neoformans, Candida albicans and other fungi bind specifically to the glycosphingolipid lactosylceramide (Gal $\beta 1-4 \mathrm{Glc} \beta 1-1 \mathrm{Cer}$ ), a possible adhesion receptor for yeasts. Infect Immun 58: 2085-2090.

Kanetsuna F 1981. Ultraestructural studies on the dimorphism of Paracoccidiodes brasiliensis, Blastomyces dermatitidis and Histoplasma capsulatum. Sabouraudia 19: 275-286.

Kanetsuna F, Carbonell LM, Gil F, Azuma I 1974. Chemical and ultrastructural studies on the cell walls of the yeast like and mycelial forms of Histoplasma capsulatum. Mycopath Mycol Appl 54: 1-13.

Kataoka K, Muta T, Yamazaki S, Takeshige K 2002. Activation of macrophages by linear (1-3)- $\beta$-D-glucans. Implications for the recognition of fungi by innate immunity. J Biol Chem 277: 36825-36831.

Klimpel KR, Goldman WE 1988. Cell walls from avirulent variants of Histoplasma capsulatum lack $\alpha-(1,3)$-glucan. Infect Immun 56: 2997-3000.

Kügler S, Schurtz-Sebghati T, Eissenberg LG, Goldman WE 2000. Phenotypic variation and intracellular parasitism by Histoplasma capsulatum. Proc Natl Acad Sci USA 97: 8794-8798.

Long KH, Gomez FJ, Morris RE, Newman SL 2003. Identification of heat shock protein 60 as the ligand on Histoplasma capsulatum that mediates binding to $\mathrm{CD} 18$ receptors on human macrophages. J Immunol 170: 487-494.

Lu J, Teh C, Kishore U, Reid KB 2002. Collectins and ficolins: sugar pattern recognition molecules of the mammalian innate immune system. Biochem Biophys Acta 1572: 387-400.

Maldonado G, Gorocica P, Agundis C, Pérez A, Molina J, Zenteno E 1998. Inhibition of phagocytic activity by the N-acetyl-D-galactosamine specific lectin from Amaranthus leucocarpus. Glyconjugates $J$ 15: 615-622.

Marion CL, Rappleye CA, Engle JT, Goldman WE 2006. An $\alpha-(1,4)-$ amylase is essential for $\alpha-(1,3)$-glucan production and virulence in Histoplasma capsulatum. Mol Microbiol 62: 970-983.
Marth T, Kelsall BL 1997. Regulation of interleukin-12 by complement receptor 3 signaling. $J$ Exp Med 185: 1987-1995.

Matsuo AL, Tersariol II, Kobata SI, Travassos LR, Carmona AK, Puccia R 2006. Modulation of the exocellular serine-thiol proteinase activity of Paracoccidioides brasiliensis by neutral polysaccharides. Microbes Infect 8: 84-91.

McCormack FX, Gibbons R, Ward SR, Kuzmenko A, Wu H, Deepe GS Jr 2003. Macrophage-independent fungicidal action of the pulmonary collectins. J Biol Chem 278: 3625-3626.

McMahon JP, Wheat J, Sobel ME, Pasula R, Downingm JF, Martin II WJ 1995. Murine laminin binds to Histoplasma capsulatum. A possible mechanism of dissemination. J Clin Invest 96: 1010-1017.

Medeiros AI, Silva CL, Malheiro A, Maffei CML, Faccioli LH 1999. Leukotrienes are involved in leukocyte recruitment induced by live Histoplasma capsulatum or by the $\beta$-glucan present in their cell wall. Br J Pharmacol 128: 1529-1537.

Meier A, Kirschning CJ, Nikolaus T, Wagner H, Heesemann J, Ebel F 2003. Toll-like receptor (TLR) 2 and TLR4 are essential for Aspergillus-induced activation of murine macrophages. Cell Microbiol 5: 561-570.

Obei LM, Okamoto Y, Mao C 2002. Yeast sphingolipids: metabolism and biology. Biochem Biophys Acta 1585: 163-171.

Pereira-Morales MA, Merchant MTN, Reyes-Montes MR, Toriello C, Agundis-Mata C, Flores-Robles E, Taylor ML 1998. Inmunolocalización del complejo polisacárido-proteína en ultraestructuras de la fase micelial y levaduriforme de Histoplasma capsulatum. Rev Ins Nal Enf Resp Mex 11: 237-242.

Rappleye CA, Eissenberg LG, Goldman WE 2007. Histoplasma capsulatum $\alpha-(1,3)$-glucan blocks innate immune recognition by the $\beta$-glucan receptor. Proc Natl Acad Sci USA 104: 1366-1370.

Rappleye CA, Engle JT, Goldman WE 2004. RNA interference in Histoplasma capsulatum demonstrates a role for $\alpha$-(1,3)-glucan in virulence. Mol Microbiol 53: 153-165.

Reiss E, Miller SE, Kaplan W, Kaufman L 1977. Antigenic, chemical and structural properties of cell walls of Histoplasma capsulatum yeast-form chemotypes 1 and 2 after serial enzymatic hydrolysis. Infect Immun 16: 690-700.

Reiss E, Mitchell WO, Stone SH, Hasenclever HF 1974. Cellular immune activity of a galactomannan-protein complex from mycelia of Histoplasma capsulatum. Infect Immun 10: 802-809.

Rementeria A, Abaitua F, Garcia-Tobalina R, Hernando F, Ponton J, Sevilla MJ 1997. Resistance to candidiasis and macrophage activity in chitin-treated mice. FEMS Immunol Med Microbiol 19: 223-230.

Roeder A, Kirschning CJ, Rupec RA, Schaller M, Weindl G, Karting HC 2004. Toll-like receptors as key mediators in innate antifungal immunity. Med Mycol 42: 485-498.

Ross GD 2002. Role of the lectin domain of Mac-1/CR3 (CD11b/CD18) in regulating intercellular adhesion. Immunol Res 25: 219-227.

Ruiz-Herrera J 1992. Chemical composition of the fungal cell wall. Isolation of cell wall. In J Ruiz-Herrera, Fungal cell wall: structure. Synthesis and assemble, CRC Press, Boca Raton, p. 5-22.

Taylor ML, Bojalil LF 1977. Inmunología de la histoplasmosis: aislamiento de un complejo polisacárido-proteína con actividad inmunoespecífica a partir de Histoplasma capsulatum. Arch Invest Med Mex 8: 91-102.

Taylor ML, Duarte-Escalante E, Pérez A, Zenteno E, Toriello C 2004. Histoplasma capsulatum yeast cells attach and agglutinate human erythrocytes. Med Mycol 42: 287-292. 
Taylor ML, Duarte-Escalante E, Reyes-Montes MR, Elizondo N, Maldonado G, Zenteno E 1998. Interaction of murine macrophagemembrane proteins with components of the pathogenic fungus Histoplasma capsulatum. Clin Exp Immunol 113: 423-428.

Taylor ML, Reyes-Montes MR, Lachica A, Eslava-Campos C, O1vera J, Maxwell R 1980. Immunology of histoplasmosis: humoral and cellular activity from a polysaccharide-protein complex and its deproteinized fraction in experimentally immunized mice. Mycopathologia 71: 159-166.

Xia Y, Vetvicka V, Yan J, Hanikyrova M, Mayadas T, Ross GD 1999. The $\beta$-glucan-binding lectin site of mouse CR3 (CD11b/CD18) and its function in generating a primed state of the receptor that mediates cytotoxic activation in response to iC $3 \mathrm{~b}$-opsonized target cells. J Immunol 162: 2281-2290. 